\title{
Review
}

\section{Science in democracy: Expertise, institutions and representation}

\author{
Mark B. Brown \\ MIT Press, Cambridge, MA and London, 2009, xvi + 354pp., £41.95/\$56.00, \\ ISBN: 978-0262513043
}

Contemporary Political Theory (2012) 11, e5-e8. doi:10.1057/cpt.2011.4

\begin{abstract}
After the 'Science Wars' of the 1990s and the 'Republican War on Science' of the 2000s in the United States, the fraught relationship between science and politics continues to make headlines. In conflicts over issues ranging from global warming to stem cell research, complaints about 'politicized science' remain familiar refrains. However, such complaints presuppose a rigid boundary that has been subjected to thorough critique: between objective, value-free science on one side and interested, power-laden politics on the other. These complaints have also accomplished little; they have not purified science from the ostensibly contaminating touch of politics, and in prominent conflicts competing interest groups remain entrenched.
\end{abstract}

Mark Brown's book constitutes an important and rigorous contribution to current efforts to move beyond these complaints. Rather than adding one more demonstration of science's intertwinement with politics, or one more call for increased public participation in science policy, Brown proposes a rethinking of democratic institutions, grounded in a conception of scientific and political representation alternative to the prevailing 'liberal-rationalist' model. At the heart of this alternative - along with the theory of democracy to which it leads - is an idea that Brown derives in various ways from Hobbes, Dewey and Bruno Latour: 'representation as practices of mediation that transform what they represent', rather than mirroring a preexisting nature or polity (p. viii). The book develops this conception through readings of canonical and recent texts in Western political thought, interspersed with reflections on connections between scientific and political representation in current practice (p. viii). In the concluding chapters, Brown discusses implications of this alternative approach for specifying the 'political' in science, identifying essential elements of democratic representation (participation is only one of them), and developing institutional practices and procedures for putting representation into operation.

(C) 2012 Macmillan Publishers Ltd. 1470-8914 Contemporary Political Theory Vol. 11, 3, e5-e8 www.palgrave-journals.com/cpt/ 
The first seven chapters, which include Brown's engaging and insightful readings of canonical thinkers, constitute the book's core. He begins with Machiavelli, whose approach to expert advice prefigures the empowerment of contemporary science advisory boards: deploying rhetoric of self-effacement and social distance, establishing the role of experts as limited but crucial, and emphasizing the design of institutions to facilitate relationships between state and citizenry. Brown traces subsequent conceptual origins of a division of labor in which an elite, elected government deliberates and legislates, heeding the advice of competent but unelected experts, while citizens vote and monitor the activities of government. First, the shift from Cartesian and Galilean rationalism to the experimentalist protocols of witnessing by gentlemanscientists makes science 'public' - albeit in a limited sense - and provides a model for the relationship in liberal democracy between competent representatives and the people (or things) they represent. This circumscription of expert deliberation advances further with Rousseau, who restricts the pursuit of scientific knowledge to geniuses, but nonetheless carves out a participatory role for the wider public: discerning the general will through internal reflection and electing an executive government capable of implementing it. Madison and Hamilton cement the liberal-rationalist division of labor by transferring to government the power to legislate, but at the cost of disconnecting representation from the represented, ultimately privileging the competence of elites over the consent of the governed as the basis of legitimacy. Brown illustrates this division of labor with a fascinating case study of transformations in the 'fair balance' provision of the United States' Federal Advisory Committee Act of 1972, which has generated controversy over what and who should be represented on such committees - and who can represent them.

In order to derive the alternative conception of representation that underlies his reflections on institutional design in the closing chapters, Brown turns to Hobbes, Dewey and Latour. Hobbes, despite his anti-democratic stance, provides the crucial idea that representation constitutes a citizenry, rather than mirroring a preexisting 'People'. Brown also finds in Hobbes' notion of 'representation by fiction' a promising way to conceive the representation of nonhumans. Dewey democratizes and extends this constitutive approach, emphasizing participation as a requirement for effective representation; he also discards the radical break between science and other ways of knowing, laying the groundwork for a non-technocratic relationship between science and democracy. Finally, Latour recasts representation in terms of translation, circulation and mediation, and as its target, replaces human subjects and nonhuman objects with heterogeneous human-nonhuman associations.

Brown's reading of Latour, the author of Politics of Nature (2004) and the only contemporary theorist to whom the book devotes a chapter, deserves close attention for the questions it raises. Although Brown enlists Latour to 
help advance the debate between constructivists and realists over scientific representation, he argues that a 'key shortcoming' in Latour's thought is 'that it remains within the basic logic of representation as substitution between represented and representative' (p. 178): the same logic that hamstrings the liberal-rationalist model. This point is debatable, given that Latour's (2003, p. 153) essay on political enunciation regimes that Brown cites also emphasizes that '(representation) has never denoted some mimetic resemblance between the represented or the representative'. Latour's treatment of representation is perhaps more complex and subtle than he receives credit for here. Similarly, Brown's characterization of Latour as 'embrac(ing) flux over fixity' (p. 181) has been persuasively challenged by Harman (2009), who provocatively calls Latour the 'anti-Bergson'. It is also unclear how Brown concludes that Latour is 'hyperskeptical' about the role of stable institutions, given Latour's (2004, p. 205) defense of record-keeping bureaucrats and administrators as custodians of 'the power to follow up' and thereby 'ensure the continuity of public life'.

Regardless of where Latour stands in the spectrum of positions on representation, the more important question is whether the alternative conception developed here can take us beyond the modern bifurcation between science and politics. The final three chapters offer some suggestive answers, but they may disappoint some readers. For Brown, science becomes political, or politicized, in situations where both power and conflict are present. This definition is unlikely to satisfy those who subscribe to Foucault's conception of power as ubiquitous and constitutive, which Brown acknowledges but quickly sets aside (p. 188), or to Latour's (1999, p. 262) contention that 'Power and Reason are one and the same'. For Brown, power is the capacity to 'elicit compliance' (p. 188) and it is something that can be distributed among individuals and groups (p. 192). The best response to science that is politicized in this sense, Brown concludes, is democratic representation through institutions including, but not limited to, government advisory councils and deliberative 'minipublics' - associated with different combinations of the elements of representation: authorization, accountability, participation, deliberation and resemblance. Although Brown's reconsiderations of the possibilities of existing institutions are reasonable and constructive, radical critics concerned about movement cooptation or otherwise suspicious of agendas for reform may remain unconvinced. The final chapter is also rather brief and mostly suggestive; perhaps there will be a sequel to this book that empirically investigates institutionalized representation in practice, both in the United States and beyond?

For its contributions to thinking about science and democracy, this book should be considered essential reading for those interested in ongoing discussions about the relationships between science and politics and 'expert' and 'lay' knowledge, and also for those involved with the rethinking of political 
representation in the wake of contemporary science studies. Brown's readings are lucid, eye-opening and likely both to provoke healthy debate and to generate interesting questions for research.

\section{References}

Harman, G. (2009) Prince of Networks: Bruno Latour and Metaphysics. Melbourne, Australia: Re-press.

Latour, B. (1999) Pandora's Hope: Essays on the Reality of Science Studies. Cambridge, MA: Harvard University Press.

Latour, B. (2003) What if we talked politics a little? Contemporary Political Theory 2(2): 143-164.

Latour, B. (2004) Politics of Nature: How to Bring the Sciences into Democracy. Cambridge, MA: Harvard University Press.

Ryan Holifield

University of Wisconsin-Milwaukee, Wisconsin, USA 